\title{
Anti-oestrogen modification of uterine responses to oestrogen in the rat
}

\author{
Ellisha Majid and Judith Senior \\ School of Studies in Pharmacology, University of Bradford, Bradford BD7 IDP, U.K.
}

\begin{abstract}
Summary. Oestradiol (single injection) resulted in a peak in uterine blood flow $3 \mathrm{~h}$ later with a secondary rise in blood flow at $30 \mathrm{~h}$. Uterine wet and dry weights increased more slowly and were still above control values $24 \mathrm{~h}$ after the injection. If a second injection of oestradiol was given $24 \mathrm{~h}$ after the first then uterine blood flow was again maximal at $3 \mathrm{~h}$ but remained at this level for a further $3 \mathrm{~h}$, probably due to the secondary rise induced by the first injection. Uterine wet weight was further increased by the second injection of oestradiol but the effect did not occur until $6 \mathrm{~h}$ after the oestrogen treatment. Pretreatment with an anti-oestrogen, tamoxifen or nafoxidine, inhibited or reduced significantly the uterine weight and uterine blood flow responses to oestrogen but increased uterine weights and produced some increase in uterine blood flow when given alone. It is suggested that both blood flow and weight responses to oestrogen in the uterus are mediated through the oestrogen receptors.
\end{abstract}

\section{Introduction}

Oestrogens are known to produce an increase in uterine blood flow and volume as well as an increase in uterine weight (Spaziani \& Suddick, 1967; Spaziani, 1975; Phaily \& Senior, 1978a). Previous work has shown that oestrogen-induced uterine blood flow evoked during the first hour after treatment may be modified by substances which inhibit the synthesis or action of histamine, kinins and prostaglandins (Phaily \& Senior, 1978b). The mechanism of action of oestrogen in inducing blood flow increases could be through the oestrogen receptors present in the uterus of the ovariectomized rat or by a direct effect on vascular smooth muscle. In the present study oestrogen-receptor antagonists have been used in an attempt to elucidate the mechanism by which oestrogen increases uterine blood flow.

\section{Materials and Methods}

Mature virgin female rats of a $C D$-derived strain from the Animal House, University of Bradford, were used throughout and were housed in light (07:00-19:00 h) and temperature $\left(18^{\circ} \mathrm{C}\right)$ controlled rooms. The animals were allowed food and tap water ad libitum. All animals were bilaterally ovariectomized and allowed to recover for at least 14 days before being used for any further experimental procedure.

Measurement of blood flow

Blood flow was measured in anaesthetized rats by the microsphere technique described in previous work (Phaily \& Senior, 1978a). In the present experiments the microspheres had a mean 
diameter of $15 \mu \mathrm{m}$ (NEN-Trac, New England Nuclear, Boston, Massachusetts, U.S.A.) and were labelled with scandium -46 and suspended in $10 \%(\mathrm{w} / \mathrm{v})$ dextran containing $0.01 \%(\mathrm{w} / \mathrm{v})$ Tween 80. Uterine blood flows were calculated using wet weights of tissues; when dry weights are quoted the tissue was dried for $48 \mathrm{~h}$ until the weight remained constant.

\section{Drugs and treatments}

Oestradiol (oestra-1,3,5,(10)-triene-3,17-diol) (BDH, Poole, Dorset, U.K.) was administered in a $10 \%(\mathrm{v} / \mathrm{v})$ solution of propylene glycol intravenously (i.v.) into the tail vein of the conscious restrained rat. Tamoxifen (I.C.I., Macclesfield, Cheshire, U.K.) and nafoxidine hydrochloride (Upjohn, Kalamazoo, Michigan, U.S.A.) were dissolved in absolute alcohol and dispersed in arachis oil before subcutaneous (s.c.) injection. The solvents used did not have any effect on uterine blood flow or weight and these results have been grouped as control values.

\section{Statistical analysis}

Results were compared using Student's $t$ test; when the samples to be compared had significantly different variances Cochran's modification was applied (Snedecor \& Cochran, 1967). The results are shown as mean \pm standard error of the mean.

\section{Results}

\section{Effect of oestradiol on uterine weight and water content}

There was a significant increase in uterine wet and dry weights and in water content $3 \mathrm{~h}$ after the injection of $0.5 \mu \mathrm{g}$ oestradiol $\mathrm{kg}^{-1}$ and this increase in weight was sustained for at least $30 \mathrm{~h}$ (Table 1). The increase in water content was greatest between 9 and $21 \mathrm{~h}$ after the injection of oestrogen. Administration of a second dose of oestradiol $24 \mathrm{~h}$ after the first gave a significant

Table 1. The effect of $0.5 \mu \mathrm{g}$ oestradiol $\mathrm{kg}^{-1}$ on uterine weight in ovariectomized rats at different times after injection

\begin{tabular}{|c|c|c|c|c|c|}
\hline \multirow{2}{*}{$\begin{array}{l}\text { Time after } \\
\text { injection }(\mathrm{h})\end{array}$} & \multirow{2}{*}{$\begin{array}{l}\text { No. of } \\
\text { rats }\end{array}$} & \multirow{2}{*}{$\begin{array}{l}\text { Body wt } \\
\text { (g) }\end{array}$} & \multicolumn{2}{|c|}{ Uterine wt (mg) } & \multirow{2}{*}{$\begin{array}{c}\text { Water } \\
\text { content }(\mathrm{mg})\end{array}$} \\
\hline & & & Wet & Dry & \\
\hline 0 (control) & 18 & $320 \pm 7$ & $92 \pm 4$ & $19 \pm 1$ & 73 \\
\hline 1.5 & 10 & $312 \pm 10$ & $99 \pm 6$ & $22 \pm 1$ & 77 \\
\hline 3 & 17 & $334 \pm 7$ & $115 \pm 5^{* * * *}$ & $22 \pm 1^{*}$ & $93^{* * *}$ \\
\hline 6 & 8 & $311 \pm 13$ & $139 \pm 6^{* * *}$ & $24 \pm 1^{* *}$ & $115^{* * *}$ \\
\hline 9 & 13 & $320 \pm 10$ & $164 \pm 5^{* * * *}$ & $27 \pm 1^{* * *}$ & $137^{* * *}$ \\
\hline 18 & 6 & $309 \pm 2$ & $168 \pm 13^{* * *}$ & $30 \pm 2^{* * *}$ & $139^{* * *}$ \\
\hline 21 & 4 & $333 \pm 5$ & $159 \pm 25^{* * *}$ & $29 \pm 5^{* *}$ & $130^{* * *}$ \\
\hline 24 & 12 & $333 \pm 9$ & $145 \pm 8^{* * *}$ & $27 \pm 2^{* * *}$ & $118^{* * *}$ \\
\hline 27 & 6 & $331 \pm 11$ & $148 \pm 19^{* * *}$ & $28 \pm 4^{* *}$ & $120^{* * * *}$ \\
\hline 30 & 8 & $313 \pm 5$ & $145 \pm 10^{* * *}$ & $26 \pm 2^{* * *}$ & $118^{* * * *}$ \\
\hline \multicolumn{6}{|l|}{ Oestradiol $24 \mathrm{~h}$} \\
\hline + Oestradiol $3 \mathrm{~h}$ & 7 & $336 \pm 11$ & $163 \pm 9$ & $27 \pm 2$ & 136 \\
\hline+ Oestradiol $6 \mathrm{~h}$ & 9 & $316 \pm 6$ & $181 \pm 13 \dagger$ & $29 \pm 2$ & $152 \dagger$ \\
\hline
\end{tabular}

Values are mean \pm s.e.m.

Values significantly different from those of the control group: ${ }^{*} P<0.05,{ }^{* *} P<$ $0.005,{ }^{* * *} P<0.001$.

+ Values significantly different from the value for oestradiol alone at $30 \mathrm{~h}: P<0.05$. 
increase in wet weight and water content when compared to the 30 -h response to a single dose of oestrogen.

\section{Effect of oestradiol on uterine blood flow}

Uterine blood flow increased rapidly following the injection of oestradiol and a maximum response was measured $3 \mathrm{~h}$ after treatment (Table 2). The increase in uterine blood flow was transient; 9-18 h after oestrogen injection the blood flow had reverted to values which were similar to those seen in the untreated animal. There was a second increase in uterine blood flow $30 \mathrm{~h}$ after the injection. Blood flow to the other organs investigated (kidney, small intestine, brain and liver) and cardiac output were not significantly affected by the oestradiol treatment over the time measured. A second injection of oestradiol given $24 \mathrm{~h}$ after the first injection significantly increased uterine blood flow $3 \mathrm{~h}$ later.

Table 2. The effect of $0.5 \mu \mathrm{g}$ oestradiol $\mathrm{kg}^{-1}$ on uterine blood flow ovariectomized rats at different times after injection

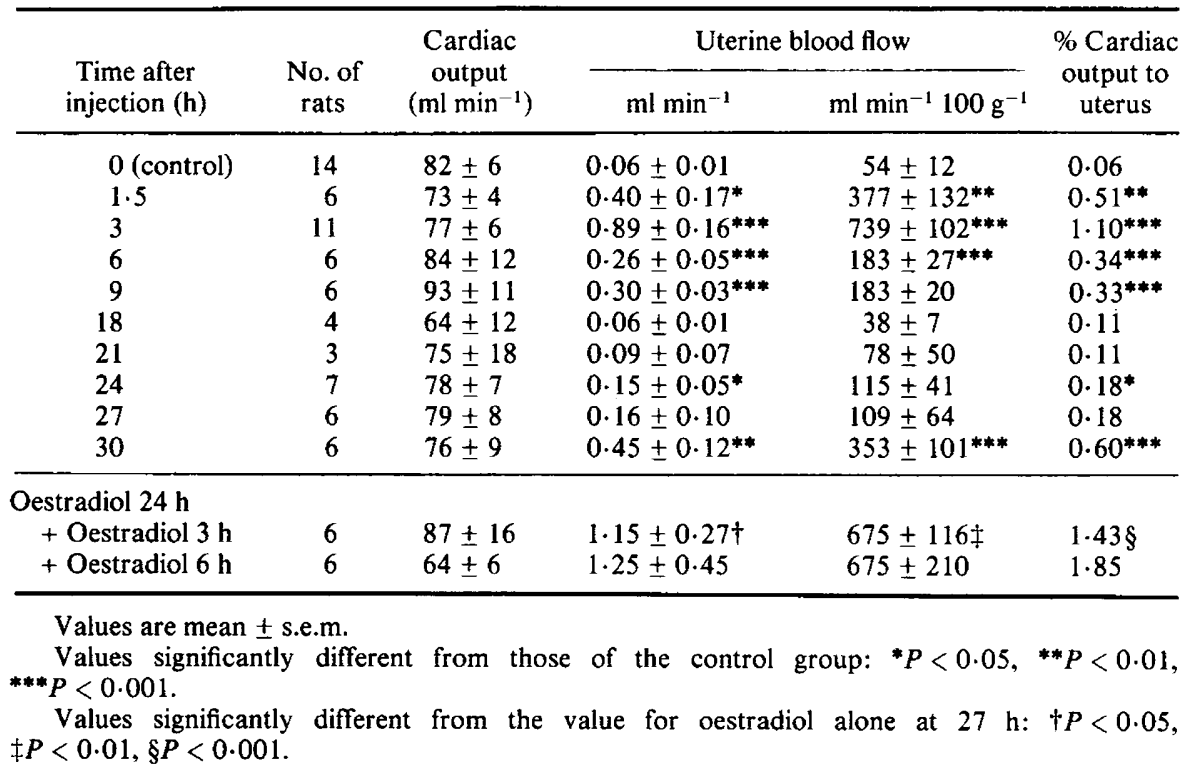

\section{Effect of tamoxifen alone and tamoxifen followed by oestradiol on uterine weight and blood flow}

Treatment with tamoxifen ( $1 \mathrm{mg} \mathrm{kg}^{-1}$ s.c.) increased the uterine wet and dry weights significantly $24 \mathrm{~h}$ after treatment. When oestradiol was administered $24 \mathrm{~h}$ after tamoxifen, there were no significant changes in uterine weights (Table 3). The effect of tamoxifen on uterine blood flow is shown in Table 4 . At 27 and $30 \mathrm{~h}$ after a single dose of tamoxifen there was a significant uterine hyperaemia. In the presence of tamoxifen the early increase in blood flow seen 3 and $6 \mathrm{~h}$ after oestradiol treatment was inhibited. Tamoxifen treatment did not have any significant effect on the blood flow through the other organs investigated (kidney, small intestine, brain and liver) and cardiac output was also unaffected by the treatment.

\section{Effect of nafoxidine alone and nafoxidine followed by oestradiol on uterine weight and blood flow}

Uterine wet and dry weights were significantly increased 14 and $17 \mathrm{~h}$ after treatment with nafoxidine, but treatment with oestradiol $17 \mathrm{~h}$ after nafoxidine injection failed to produce any 
Table 3. The effect of $1 \mathrm{mg}$ tamoxifen $\mathrm{kg}^{-1}$ alone and in the presence of $0.5 \mu \mathrm{g}$ oestradiol $\mathrm{kg}^{-1}$ on uterine weight in the ovariectomized rat at different times after injection

\begin{tabular}{|c|c|c|c|c|c|}
\hline \multirow[b]{2}{*}{ Treatment } & \multirow{2}{*}{$\begin{array}{l}\text { No. of } \\
\text { rats }\end{array}$} & \multirow{2}{*}{$\begin{array}{l}\text { Body wt } \\
\text { (g) }\end{array}$} & \multicolumn{2}{|c|}{ Uterine wt (mg) } & \multirow{2}{*}{$\begin{array}{c}\text { Water } \\
\text { content }(\mathrm{mg})\end{array}$} \\
\hline & & & Wet & Dry & \\
\hline \multicolumn{6}{|l|}{ Tamoxifen alone } \\
\hline $24 \mathrm{~h}$ & 14 & $301 \pm 7$ & $161 \pm 9$ & $30 \pm 2$ & 132 \\
\hline $27 \mathrm{~h}$ & 7 & $298 \pm 10$ & $157 \pm 10$ & $28 \pm 1$ & 130 \\
\hline $30 \mathrm{~h}$ & 7 & $328 \pm 8$ & $133 \pm 8$ & $24 \pm 1$ & 109 \\
\hline $33 \mathrm{~h}$ & 6 & $332 \pm 6$ & $158 \pm 5$ & $29 \pm 1$ & 129 \\
\hline \multicolumn{6}{|l|}{ Tamoxifen $24 \mathrm{~h}$} \\
\hline + Oestradiol $3 \mathrm{~h}$ & 11 & $308 \pm 11$ & $182 \pm 11$ & $32 \pm 2$ & 150 \\
\hline+ Oestradiol $6 \mathrm{~h}$ & 9 & $317 \pm 10$ & $168 \pm 16$ & $28 \pm 2$ & 140 \\
\hline + Oestradiol $9 \mathrm{~h}$ & 6 & $338 \pm 4$ & $153 \pm 8$ & $28 \pm 1$ & 129 \\
\hline
\end{tabular}

Values are mean $t$ s.e.m.

Table 4. The effect of $1 \mathrm{mg}$ tamoxifen $\mathrm{kg}^{-1}$ alone and in the presence of $0.5 \mu \mathrm{g}$ oestradiol $\mathrm{kg}^{-1}$ on uterine blood flow in ovariectomized rats at different times after injection

\begin{tabular}{|c|c|c|c|c|c|}
\hline \multirow[b]{2}{*}{ Treatment } & \multirow{2}{*}{$\begin{array}{l}\text { No. of } \\
\text { rats }\end{array}$} & \multirow{2}{*}{ 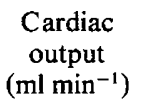 } & \multicolumn{2}{|c|}{ Uterine blood flow } & \multirow{2}{*}{$\begin{array}{c}\% \text { Cardiac } \\
\text { output to } \\
\text { uterus }\end{array}$} \\
\hline & & & $\mathrm{ml} \mathrm{min}-1$ & 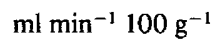 & \\
\hline \multicolumn{6}{|l|}{ Tamoxifen alone } \\
\hline $24 \mathrm{~h}$ & 6 & $78 \pm 9$ & $0.14 \pm 0.03$ & $103 \pm 32$ & $0 \cdot 18$ \\
\hline $27 \mathrm{~h}$ & 6 & $77 \pm 8$ & $0.42 \pm 0.11$ & $265 \pm 63$ & 0.55 \\
\hline $30 \mathrm{~h}$ & 6 & $81 \pm 5$ & $0.30 \pm 0.11$ & $211 \pm 67$ & 0.40 \\
\hline \multicolumn{6}{|l|}{ Tamoxifen $24 \mathrm{~h}$} \\
\hline + Oestradiol $3 \mathrm{~h}$ & 6 & $83 \pm 16$ & $0.28 \pm 0.06$ & $163 \pm 42$ & 0.40 \\
\hline + Oestradiol $6 \mathrm{~h}$ & 6 & $98 \pm 7$ & $0.49 \pm 0.14$ & $292 \pm 62$ & 0.47 \\
\hline
\end{tabular}

significant increase in uterine wet or dry weight $3 \mathrm{~h}$ later (Table 5). Nafoxidine alone increased uterine blood flow significantly 14 and $17 \mathrm{~h}$ after injection but nafoxidine plus oestradiol had no significant effect (Table 5).

\section{Discussion}

The temporal patterns of the increase in uterine weight and blood flow after oestradiol injection were different. The initial peak uterine blood flow was transient and occurred about $3 \mathrm{~h}$ after oestradiol treatment, a secondary increase in blood flow occurred around $30 \mathrm{~h}$ after the oestrogen injection. The increase in wet and dry weight of the uterus was not apparent until $3 \mathrm{~h}$ after oestrogen treatment and maximum effects were not seen until between 9 and $21 \mathrm{~h}$ although the uterine weight was still significantly raised $30 \mathrm{~h}$ after the single injection. The maximum increase in uterine weight was not so dramatic as that of blood flow; the wet and dry weight increases were 83 and $53 \%$ respectively compared with a $1268 \%$ increase in blood flow. Other studies have shown that the pattern of wet weight increase after a single injection of oestradiol is 
Table 5. The effect of $1 \mathrm{mg}$ nafoxidine hydrochloride $\mathrm{kg}^{-1}$ alone and in the presence of $0.5 \mu \mathrm{g}$ oestradiol $\mathrm{kg}^{-1}$ on uterine weight and blood flow in ovariectomized rats at different times after injection

\begin{tabular}{|c|c|c|c|}
\hline & \multicolumn{2}{|c|}{ Nafoxidine } & \multirow{2}{*}{$\begin{array}{l}\text { Nafoxidine } 14 \mathrm{~h} \\
+ \text { oestradiol } 3 \mathrm{~h}\end{array}$} \\
\hline & $14 \mathrm{~h}$ & $17 \mathrm{~h}$ & \\
\hline No. of rats & 8 & 7 & 6 \\
\hline Body wt (g) & $346 \pm 10$ & $338 \pm 5$ & $333 \pm 8$ \\
\hline \multicolumn{4}{|l|}{ Uterine wt (mg) } \\
\hline Wet & $156 \pm 11$ & $160+9$ & $146 \pm 8$ \\
\hline Dry & $24 \pm 1$ & $26 \pm 1$ & $23 \pm 1$ \\
\hline Water content (mg) & 132 & 133 & $1 \overline{23}$ \\
\hline No. of rats & 6 & 6 & 6 \\
\hline \multicolumn{4}{|l|}{ Cardiac output } \\
\hline$(\mathrm{ml} \mathrm{min}-1)$ & $84 \pm 5$ & $85 \pm 10$ & $80 \pm 8$ \\
\hline \multicolumn{4}{|l|}{ Uterine blood flow } \\
\hline $\mathrm{ml} \mathrm{min}^{-1}$ & $0.25 \pm 0.03$ & $0.30 \pm 0.09$ & $0.44 \pm 0.08$ \\
\hline $\mathrm{ml} \mathrm{min}-1100 \mathrm{~g}^{-1}$ & $153 \pm 23$ & $175 \pm 46$ & $295 \pm 48$ \\
\hline \multicolumn{4}{|l|}{$\%$ cardiac output } \\
\hline to uterus & $0 \cdot 28$ & 0.33 & 0.53 \\
\hline
\end{tabular}

Values are mean \pm s.e.m.

also that of an early peak at about $8 \mathrm{~h}$ but the present studies showed a second peak beyond $30 \mathrm{~h}$, between 31.5 and $54 \mathrm{~h}$ (Astwood, 1938; Cole, 1950). It may be that peak increases in uterine weight require a prior increase in uterine blood flow in the preceding $1-2 \mathrm{~h}$ to ensure that the weight response occurs.

It is generally accepted that oestradiol-induced uterine growth is mediated through an oestrogen receptor mechanism. The oestrogen receptor concept (Jensen et al., 1968) has now been extended to include a second type of binding site (Markaverich \& Clark, 1979; Eriksson, Hardin, Markaverich, Upchurch \& Clark, 1980). Classical oestrogen receptors (type I) only show oestradiol occupancy for around $24 \mathrm{~h}$ but type II receptors have been demonstrated in vitro to bind oestradiol for up to $72 \mathrm{~h}$. Both types of receptor may be involved in the uterine weight response to oestradiol but within the limits of the results reported in this paper probably only type I receptors are involved. Anti-oestrogens have been shown to bind to type I receptors and the receptor complex so formed translocates into the cell nucleus, thus depleting the cytoplasm of receptors. With nafoxidine the cytoplasm is depleted of receptors by $1 \mathrm{~h}$ after treatment and this depletion lasts for at least $24 \mathrm{~h}$ (Clark, Anderson \& Peck, 1973; Katzenellenbogen \& Ferguson, 1975; Ruh \& Baudendistel, 1977). Similar results have been obtained showing a depletion of cytoplasmic receptors in the rat uterus $24 \mathrm{~h}$ after a single injection of tamoxifen (Davies, Syne \& Nicholson, 1979). Thus, anti-oestrogen treatment brings about a marked alteration in the distribution of oestrogen receptors and only about $10 \%$ remain in the cytoplasm (Katzenellenbogen, Ferguson \& Lan, 1977). Both tamoxifen and nafoxidine increased uterine weight, the increases being similar to that produced by oestradiol. However, the anti-oestrogenic events following nuclear binding differ from those produced by oestrogen despite both types of compound being able to produce a uterotrophic response (Clark \& Peck, 1976; Ruh \& Baudendistel, 1977; Jordan, Dix, Rowsby \& Prestwich, 1977). Tamoxifen modified the uterotrophic response to oestradiol; a small increase in uterine weight occurred within $3 \mathrm{~h}$ of the oestrogen treatment but had disappeared by $9 \mathrm{~h}$. Nafoxidine inhibited the oestrogen-induced uterotrophic response, suggesting that cytoplasmic receptors were unavailable to oestrogen. Anti-oestrogen pretreatment also blocked the oestradiol-mediated increase in 
uterine blood flow $3 \mathrm{~h}$ after the oestrogen treatment, indicating that the uterine blood flow response may also be mediated through the oestrogen-receptor mechanism.

Phaily \& Senior (1978a) showed that inhibition of the action of prostaglandins, histamine or kinins reduced the uterine hyperaemia induced by oestrogen. Tamoxifen inhibits prostaglandin synthesis in vitro (Fenwick, Jones, Naylor, Poyser \& Wilson, 1977; Sharma \& Pugh, 1977) but this is unlikely to be the mechanism by which this anti-oestrogen inhibits the uterine blood flow response to oestrogen because inhibition of prostaglandin synthesis alone only reduced the response by $50 \%$ (Phaily \& Senior, 1978a). Inhibition of the action of prostaglandins, kinins and histamine was needed to abolish the oestrogen-induced uterine hyperaemia (Phaily \& Senior, 1978b). Furthermore, nafoxidine, which is not known to be a prostaglandin synthesis inhibitor, also inhibited oestrogen-induced uterine blood flow.

When oestradiol was injected $24 \mathrm{~h}$ after the first injection of oestradiol there was an increase in blood flow within $3 \mathrm{~h}$ and an increase in weight within $6 \mathrm{~h}$ showing that the uterus was capable of responding to the second injection of oestrogen. Other workers have shown daily repeatable uterine blood flow responses to oestradiol in the ewe (Killam, Rosenfeld, Battaglia, Makowski \& Meschia, 1973). Hence, the failure of oestrogen to affect uterine blood flow after treatment with anti-oestrogens appears to be due to the effect of the antagonists on receptor mechanisms, an effect which does not occur when repeated doses of agonists are given.

To reconcile the involvement of both receptor action and local hormones in the uterine blood flow response 1-3 $\mathrm{h}$ after oestrogen it is suggested that receptor binding is probably required to initiate local hormone release. The time scale of the blood flow response would be consistent with receptor-interaction events. As blood flow rates through the uterus increase, then other events such as entry of water and solutes into cells follow, in turn to be followed by protein synthesis and cell replication.

We thank Dr B. J. A. Furr (I.C.I.) for the gift of tamoxifen and Dr P. W. O'Connell and Mr M. Harvey (Upjohn) for the gift of nafoxidine.

\section{References}

Astwood, E.B. (1938) A six-hour assay for the quantitative determination of estrogen. Endocrinology 23, 25-31.

Clark, J.H. \& Peck, E.J. (1976) Nuclear retention of receptor oestrogen complex and nuclear acceptor sites. Nature, Lond. 260, 635-637.

Clark, J.H., Anderson, J. \& Peck, E.J. (1973) Oestrogen receptor anti-oestrogen complex: atypical binding by uterine nuclei and effects on uterine growth. Steroids 22, 707-718.

Cole, D.F. (1950) The effects of oestrogen on the rat uterus. J. Endocr. 7, 12-23.

Davies, P., Syne, J.S. \& Nicholson, R.I. (1979) Effects of estradiol and the antiestrogen tamoxifen on steroid hormone receptor concentration and nuclear ribonucleic acid polymerase activities in rat uteri. Endocrinology 105, 1336-1342.

Eriksson, H.A., Hardin, J.W., Markaverich, B., Upchurch, S. \& Clark, J.H. (1980) Oestrogen binding in the rat uterus: heterogeneity of sites and relation to uterotrophic response. J. Steroid Biochem. 12, 121-130.

Fenwick, L., Jones, R.L., Naylor, B., Poyser, N.L. \& Wilson, N.H. (1977) Production of prostaglandins by the pseudopregnant rat uterus in vitro, and the effect of tamoxifen with the identification of 6 - keto-prostaglandin $\mathrm{F}_{1} \alpha$ as a major product. $\mathrm{Br} . J$. Pharmac. 59, 191-199.

Jensen, E.V., Suzuki, T., Kawashima, T., Stumpf, W.E., Jungblut, P.W. \& DeSombre, E.R. (1968) A 2-step mechanism for the interaction of estradiol with rat uterus. Proc. natn. Acad. Sci. U.S.A. 59, 632-638.

Jordan, V.C., Dix, C.J., Rowsby, L. \& Prestwich, G. (1977) Studies on the mechanism of action of the non-steroidal anti-oestrogen tamoxifen (ICI 46,474) in the immature rat. Molec. cell. Endocr. 7, 177-192.

Katzeneilenbogen, B.S. \& Ferguson, E.R. (1975) Antiestrogen action in the uterus: biological ineffectiveness of nuclear bound estradiol after antiestrogen. Endocrinology 97, 1-12.

Katzenellenbogen, B.S., Ferguson, E.R. \& Lan, N.C. (1977) Fundamental differences in the action of estrogens and antiestrogens on the uterus: comparison between compounds with similar duration of action. Endocrinology 100, 1252-1259.

Killam, A.P., Rosenfeld, C.R., Battaglia, F.C., Makowski, E.L. \& Meschia, G. (1973) Effect of estrogens on the uterine blood flow of oophorectomized ewes. Am. J. Obstet. Gynec. 115, 10451052.

Markaverich, B.M. \& Clark, J.H. (1979) Two binding sites for estradiol in rat uterine nuclei: relationship to 
uterotrophic response. Endocrinology 105, 14581462.

Phaily, S. \& Senior, J. (1978a) Modification of oestrogen-induced uterine hyperaemia by drugs in the ovariectomized rat. J. Reprod. Fert. 53, 91-97.

Phaily, S. \& Senior, J. (1978b) Inhibition of oestrogeninduced increase in uterine blood flow in the rat. $J$. Pharm. Pharmac. 30, 734-735.

Ruh, T.S. \& Baudendistel, L.J. (1977) Different nuclear binding sites for antiestrogen and estrogen receptor complexes. Endocrinology 100, 420-426.

Sharma, S.C. \& Pugh, D.M. (1977) The effect of tamoxifen on the in vitro production of prosta- glandins $\mathrm{E}$ and $\mathrm{F}$ by the guinea-pig uterine tissue. Eur. J. Pharmac. 42, 91-92.

Snedecor, G.W. \& Cochran, W.G. (1967) The comparison of two samples. In Statistical Methods, pp. 91-119. Iowa State University Press, Ames.

Spaziani, E. (1975) Acessory reproductive organs in mammals: control of cell and tissue transport by sex hormones. Pharmac. Rev. 27, 207-286.

Spaziani, E. \& Suddick, R.P. (1967) Hexose transport and blood flow rate in the uterus: effects of estradiol, puromycin and actinomycin D. Endocrinology 81, 205-212.

Received 21 October 1981 